\title{
PIONEER
}

VOLUME 11, Issue 2, December 2019: 288 - 301

\section{THE IMAGE OF WOMEN IN THE POETRY OF THE MARSINAH FALL BY SAPARDI DJOKO DAMONO: FEMINISM APPROACH}

\author{
${ }^{1}$ Muhammad Aditya Wisnu Wardana* \\ ${ }^{1}$ Universitas Sebelas Maret, Indonesia \\ laditya_wisnu246@student.uns.ac.id, \\ ${ }^{2}$ Chafit Ulya \\ ${ }^{2}$ Universitas Sebelas Maret, Indonesia \\ ${ }^{2}$ chafit@staff.uns.ac.id
}

*Corresponding author: aditya_wisnu246@student.uns.ac.id

Received : November 14, 2021 Revised : December 2, 2021

Accepted : December 9, $2021 \quad$ Published : December 30, 2021

\begin{abstract}
The poem Dongeng Marsinah by Sapardi Djoko Damono is one of the literary works that comes with an approach to the study of feminism and the image of women to respond to people's lives today. The data collection technique uses document analysis based on feminist literary theory. The interesting thing in the poem entitled Dongeng Marsinah by Sapardi Djoko Damono is the emergence of a women's movement against injustice or patriarchy through a literary work. The theory used is based on feminism literary theory with a sociological approach to literature. The view of literary works in the poem entitled Dongeng Marsinah by Sapardi Djoko Damono has a reflection on today's social life. The representation of women in the poem Dongeng Marsinah by Sapardi Djoko Damono include: (1) the representation of women from a psychological perspective; (2) the representation of women in society; (3) the representation of women in terms of behavior; and (4) the representation of women from a physical point of view. The hope is that by understanding the meaning of the image of women in the poem, a woman should not be treated with violence physically, mentally, or sexually.
\end{abstract}

Keywords: feminism, Indonesia literature, Marsinah, Sapardi Djoko Damono

\section{INTRODUCTION}

Literary works are a reflection of society and social life. The color of the character and social life of society is depicted in every literary work. Various applications of character, social upheaval in society, have inspired the birth of literary works throughout the ages. The theme of literary works underlies the story as an entertaining dish in every series of events. In reality, literary works cannot be separated from the condition of 
society in the creation of literature. In modern times like this with its various advances from a literary theory that influences people's lives. Literary studies do not only provide a soul or inner satisfaction. to the reader, but also as a means or medium for delivering a message by the creator of a literary work (Pradopo, 1995).

The creation of literary works is a reflection of the author in giving views to the reader about a social situation or social environment of society with various scopes of existing problems. Literary works have inspired human life from time to time. The types produced are very diverse and unique from time to time. Literary works that are widely created and enjoyed by the public are literary works of poetry. According to Kosasih poetry is one type of literary work that has the characteristic that it uses beautiful words and is rich in meaning (Novel et al., 2021). In this sense, it can be concluded that literary works of poetry are one of the works that are in great demand by the public, this is because poetry has a beautiful wording in conveying a message or meaning.

In the depiction of a character in a literary work, many describe women as weak. Thus, women's rights or obligations are always viewed in terms of oppression, such as women-only having duties in the kitchen, bed, and well. The basis for analyzing literature in the study of feminism is because society still views women as weak and always oppressed compared to men (Wijayanti \& Siroj, 2020). With the existence of a label that exists in society about this view, it creates a perception that continues to be embedded in society that considers a lot of injustice and violence against women as a matter of course. This is certainly a problem that needs to be studied together that a woman should get justice without violence (Djajanegara, 2002).

The author was interested in researching by analyzing the theory and criticism of feminism in one of Sapardi Djoko Damono's poems entitled Dongeng Marsinah because there were many criticisms and assumptions that women were weaker than men. By understanding the meaning of Dongeng Marsinah by Sapardi Djoko Damono, it could be seen that the poem was full of history, politics, and social phenomena. Marsinah as the main character described in the poetry was plotted in such a way to represent feminism.

In reality, Marsinah was described by Sapardi Djoko Damono as a female fighter in fomenting injustice during the New Order era and a factory employee. It was told that Marsinah always received threats which she was later kidnapped and found murdered on May 8, 1993. Sapardi Djoko Damono's poem Dongeng Marsinah clearly described the 
life of the character and the background of an event that occurred. The characteristics of feminism and criticism depicted in the poem was in line with the meaning contained in the poem that showed women were the oppressed.

Based on the views above, the author takes the title of the study of Feminism and the Image of Women in the Marsinah Fairy Tale Poem by Sapardi Djoko Damono. The poem Dongeng Marsinah has the depiction of feminism theory and the image of women in literary works.

\section{REVIEW OF LITERATURE}

\section{Poetry}

Poetry according to (Sulkifli \& Marwati, 2016) is a form of literary work that expresses the thoughts and feelings of the poet imaginatively and is composed by concentrating all the power of language by concentrating its physical structure and inner elements. Pradopo (1995) expresses poetry as something poetic. Poetic means containing beauty in the poem. Beauty in poetry cannot be defined with certainty. Poetry can be said to be poetic if it is able to evoke feelings, attract attention, generate clear responses, or give emotion. Poetry itself can arise in various ways, including visual forms: typography, stanza arrangement; with sound: rhyme, assonance, alliteration, figurative sound, symbol of taste, and orchestration. In addition, it can also be word selection (diction), figurative language, rhetorical means, grammatical elements, language style, and so on.

\section{Feminism Theory}

Feminism is a movement for equality between men and women in all fields of politics, economics, education, social and organized activities that defend the rights and interests of women. Feminism is an awareness of the oppression and extortion of women in society, both at work and at home (Novel et al., 2021). Feminist theory differs from most sociological theories in many ways. This theory is the thought of an interdisciplinary community, which includes not only sociologists but also scholars from other disciplines such as creative writers and political activists.

In literature, feminism is related to the concept of feminist literary criticism, namely the study of literature that directs the focus of analysis to women (Nugraha, 2021). Feminism in general discusses issues regarding women associated with emancipation, the 
movement demands women's rights equal to men's rights in various fields. However, it should be underlined that feminism is not a rebellion against women as an effort to fight against the nature of women such as in the household and marriage, but rather as an effort to end the oppression, violence, and exploitation that is happening to women today.

\section{METHOD}

In this study, the data source used by the researcher is the 2015 poetry anthology book Folding the Distance by Sapardi Djoko Damono. This research focuses on the study of feminism and the image of women. The data collection technique used in analyzing the language was errors the read-note method. The researcher collected the data by carefully reading the poem Dongeng Marsinah. Then, the data were classified based on the study of feminism and the image of women. This study employed qualitative research methods. According to Ibnu in Sutopo (2002), qualitative research is a research that has data in verbal form, and then an analysis is carried out without using statistical techniques. So, it can be concluded that qualitative research is a study in which the data are expressed in verbal form, not using numbers and without using statistical techniques (Sutopo, 2002). The researcher used library research framework both in gathering and analyzing by conducting a study of books, journals, and reports that are related to the topic of feminism literary theory.

\section{FINDINGS AND DISCUSSION}

\section{Findings}

Based on the research conducted and the analysis of various studies or literary theories, Feminism theory research in the poem entitled Dongeng Marsinah by Sapardi Djoko Damono provides an image or description of women implicitly or explicitly in the poem. In this study, using an approach with feminism theory to examine the image of women and the theory of feminism in the poem Dongeng Marsinah by Sapardi Djoko Damono, here are some values of feminism and the image of women that the researchers found in the poem Dongeng Marsinah by Sapardi Djoko Damono.

\section{A. The Image of Women from a Psychic and Psychological Perspective}

Marsinah buruh pabrik arloji, mengurus presisi:

merakit jarum, sekrup. Dan roda gigi; 
waktu memang tak pernah kompromi, ia sangat cermat dan pasti.

Marsinah itu arloji sejati, tak lelah berdetak memintal kefanaan

yang abadi:

"kami ini tak banyak kehendak, sekedar hidup layak, sebutir nasi." (Sapardi Djoko Damono, 2015)

English translation:

Marsinah was a watch factory worker, taking care of precision:

assembled needles, screws, and gears;

time never compromised

it was very careful and sure.

Marsinah was a true watch, not tired of beating spinning mortality that was eternal:

"we don't have much will. just a decent life, a grain of rice." (Sapardi Djoko Damono, 2015)

In the excerpt of the text of the poem, it is clearly illustrated that Marsinah is a female character, most women who are seen from a psychological point of view have accuracy and persistence in doing work, which is stated in the poetry text. She is very careful and sure. Marsinah is described here by Sapardi Djoko Damono as a female figure. great and strong struggle to provide for the needs of the family. Marsinah is also described as the breadwinner of the family who works to fulfill daily life (Jenggawah et al., 2010).

From the results of the analysis, it can be observed that apart from being a housewife, Marsinah is also a factory worker, this makes Marsinah a woman who has a dual task, namely taking care of domestic affairs and having a public role. This can be interpreted that the image of women here should not be underestimated and not underestimated, because women are someone who has a strong soul in managing life as housewives and the backbone of the family to meet daily needs. 


\section{B. The Image of Women in terms of Community Social Life}

Marsinah, kita tahu, tak bersenjata, ia hanya suka merebus kata sampai mendidih, lalu meluap ke mana-mana. "Ia suka berpikir," kata Siapa, “itu sangat berbahaya.” (Sapardi Djoko Damono, 2015)

English translation:

Marsinah, we know, was unarmed, she just liked to boil words until it boiled, then overflew everywhere. "She likes to think," said Who, "It's very dangerous." (Sapardi Djoko Damono, 2015)

In the text of the poem, it is illustrated that there is a stereotype of women in society who are often seen as always talking about something bad or gossiping so that it causes problems everywhere, this is in the text. She just likes to boil words until they boil, then overflow everywhere. However, Sapardi Djoko Damono describes Marsinah in his poetry as a woman who is intelligent and smart in speaking to voice her every aspiration. Marsinah is told here as a watch factory worker who voices her every aspiration to fight for her rights as a worker. But Marsinah's attitude gives some people discomfort.

As for the results of the analysis on the text of the poem above, he only likes to boil words until they boil, then overflows everywhere and he is very dangerous. The text of the poem shows that Marsinah as a female figure is given labels or stereotypes, that women mostly like to talk about bad things or gossip to create problems for other people, so the conversations that Marsinah or women do mostly cause problems (Olifia, 2016).

\section{E. The Image of Women in terms of Behaviour}

Marsinah tak ingin menyulut api, ia hanya memutar jarum arloji agar sesuai dengan matahari. "Ia tahu hakikat waktu," kata Siapa, "dan harus dikembalikan ke asalnya, debu." (Sapardi Djoko Damono, 2015) 
English translation:

Marsinah didn't want to start a fire,

She just turned the clock

to match the sun.

"She knows the nature of time," said Who,

"and must be returned"

to its origin, dust." (Sapardi Djoko Damono, 2015)

Marsinah in the poem Dongeng Marsinah by Sapardi Djoko Damono is described as a brave and intelligent woman. Behind her courage, Marsinah is described as a figure who is always oppressed and is considered to be clueless so that some people who hate her see Marsinah as a threat and emotion.

This poem, the Dongeng Marsinah by Sapardi Djoko Damono, tells about the case of Marsinah who was kidnapped, tortured, killed, and it is not clear who was behind the murder. This can be seen in the sentence who said. As a woman, Marsinah's case should be thoroughly investigated regardless of economic situation or gender, so that women have the same rights as men in upholding justice.

\section{F. The Image of Women from a Physical Point of View}

Di hari baik bulan baik,

Marsinah dijemput di rumah tumpangan

untuk suatu perhelatan.

Ia diantar ke rumah Siapa,

ia disekap di ruang pengap,

ia diikat ke kursi;

mereka kira waktu bisa disumpal

agar lengkingan detiknya

tidak kedengaran lagi. (Sapardi Djoko Damono, 2015)

English translation:

On the good day of the good month,

Marsinah was picked up at the boarding house

for an event.

She was taken to Who's house,

She was locked up in a stuffy room,

She was tied to a chair;

they thought time could be gagged

so that the seconds' shrill

not heard anymore. (Sapardi Djoko Damono, 2015) 
The description of the text of the poem provides a picture of the image of women from the physical aspect. Then from the sentence above, an analysis can be taken of the description of the condition of women who are victims of violence and receive disrespectful treatment as women (Wijayanti \& Siroj, 2020). As for the results of the analysis of the sentence, he was locked up in a stuffy room and tied to a chair. The data above shows that women have a weak nature, so they should not receive inhumane treatment in the form of physical, psychological, and sexual torture (Mustofa et al., 2013). The text of the poem also describes Marsinah as a threat to some people, to the point that she has to be forcibly picked up at her house. In the text of the poem, it is also illustrated that women are weak, and are always treated with violence (N. Hamidah, Endang, n.d.).

Sapardi Djoko Damono describes the poem Dongeng Marsinah through various atmosphere that will cause emotional feelings that are experienced not only for female readers but also for male readers who read the text of the poem. The depiction of Marsinah's character as a woman who experiences cruelty and violence until the end of her life is illustrated in the following excerpt of the text of the poem.

\section{G. Image of Women from Physical Treatment}

Ia tidak diberi air, ia tidak diberi nasi; detik pun gerah berloncatan ke sana ke mari.

Dalam perhalatan itu, kepalanya ditetak, selangkangnya diacak-acak, dan tubuhnya dibirulebamkan dengan besi batangan.

Detik pun tergeletak, Marsinah pun abadi. (Sapardi Djoko Damono, 2015)

English translation:

She was not given water, She was not given rice; even the seconds felt hot jumping here and there. in that celebration, her head was hit, her crotch was ruffled, and her body was bruised 
with iron bars.

the seconds fell down,

Marsinah was immortal. (Sapardi Djoko Damono, 2015)

The text of the poem describes a woman being treated inhumanely. Treatments ranged from not giving food and drinking to physical violence as well as sexual violence experienced by Marsinah. It described the treatment of a woman with violence. The text of the poem describes the treatment of women who are considered weak and helpless to the point of having to accept physical and sexual violence until the end of their lives (Endang, n.d.).

As for the results of the analysis of the text of the poem above, she was not given water, she was not given rice and her head was cut in the groin, and her body was full of bruises. In the text of the poem, Marsinah is shown as a woman who is treated inhumanely, in the poem, women are also described as weak so that they always get violence, both physically and sexually (Zulfadli, 2018).

\section{H. The Image of Women from the Treatment and Feelings of the Soul}

Semak-semak yang tak terurus

dan tak pernah ambil peduli, meregang waktu bersaksi:

Marsinah diseret

dan dicampakkan-

sempurna, sendiri.

Pangeran, apakah sebenarnya

inti kekejaman? Apakah sebenarnya

sumber keserakahan? Apakah sebenarnya

azas kekuasaan? Dan apakah sebenarnya

hakikat kemanusiaan, Pangeran? Apakah ini? Apakah itu?

Duh Gusti, apakah pula

makna pertanyaan? (Sapardi Djoko Damono, 2015)

English translation:

Unmanaged bushes

and never cared,

stretching the time to testify:

Marsinah was dragged

and dumped -

perfect, alone.

Prince, is it really

the cruelty? Is it really 
source of greed? Is it really

the principle of power? And is it really

the nature of humanity, Prince? Is this? What's that?

Oh Lord, what is it?

the meaning of the question? (Sapardi Djoko Damono, 2015)

In the text of the poem, it is clearly described that Marsinah is a woman who did not understand anything until she was hurt badly without a sense of humanity.

The text of the poem describes the image of a woman from a physical point of view. As stated in the sentence, an illustration can be drawn of the condition of women who are tortured and should not be obtained because of their physical limitations. In the text of the poem, it is clearly described that Marsinah is a woman who does not understand anything until she gets cruelty and violence without a sense of humanity (Dipa Nugraha, 2021).

As for the results of the analysis of the data described above, Marsinah was sentenced, dragged, thrown, and was tied to a chair. The data indicated that a woman always gets tortured and violence, which should not be done to women. It can be shown from the text that Marsinah as a woman gets oppression and dumps, this is what describes Marsinah as a woman who has weaknesses.

\section{Image of Women from the Viewpoint of Society}

"Sengsara betul hidup di sana

jika suka berpikir,

jika suka memasak kata;

apa sebaiknya menggelinding saja

bagai bola sodok,

bagai roda pedati?" (Sapardi Djoko Damono, 2015)

English translation:

"It's pathetic to live there

if you like to think,

if you like cooking the words;

should it just roll?

like a billiard ball,

like a wagon wheel?" (Sapardi Djoko Damono, 2015) 
The results of the description of the text of the poem above show that there is gender inequality insubordination, a condition where women are below men so that most women are not considered important in various activities. What sentence should just roll like a Pokeball describing women are not allowed to express their aspirations or opinions, this is because Marsinah as a woman is considered not to understand anything, but Sapardi Djoko Damono describes Marsinah as a woman who is brave in opposing injustice.

\section{Discussion}

Based on the results of the study, obtained from the values of women. Stating that feminism theory is not only about understanding, but also about action. Feminism itself, forms an awareness that is built by the typical experience of women about truth, knowledge, and power. Awareness of oppression is rising in all parts of the world. Feminism theory used to solve women's problems, research that focuses on the role and position of women in all aspects of life. Milech (1991, p. 120) states that feminist literary theory "shows that socially constructed masculine and feminine identities, as well as differences in access to social power and privileges that accompany these identities, shape writing and reading. any kind of text. This theory is used as a tool to consider what happens between women and men. As well as the perception of society in the poem "Fairy Tale Marsinah" by Sapardi Djoko Damono.

The patriarchal system, if dissected, is actually more about what happens between men. Although the oppression of women is part of the patriarchal system, actually the oppression of women is not the main point of the patriarchal system. It is this system that makes men compete in the dynamics of control and fear. In this system, men are directed to the nature of competitive, aggressive, oppressive (A. G. Johnson, 1997, p. 26). In a system that places men as the center and dominant like this, then men assume that women are indeed to fulfill men's needs and this assumption is also present in the minds of some women (Becker, 1999, pp. 24-25). . Women then become trophies that are contested by and can sustain the status of men in the competition between men.

Marsinah is described by Sapardi Djoko Damono as a female watch factory worker who died due to torture and violence. Marsinah in real life is depicted as a woman activist and factory worker during the New Order era, who was kidnapped and found murdered on May 8, 1993 after missing for three days. His body was found in the forest 
of Jegong Hamlet, Wilangan Village with marks of severe torture on his body (Sulkifli \& Marwati, 2016).

In the poem Dongeng Marsinah by Sapardi Djoko Damono, the life of the character and the background of an event is clearly described. The meaning of feminism and strong criticism contained in the poem is in line with the meaning contained in the poems At One Night, Mother, Sita all have the meaning that women are the oppressed.

\section{CONCLUSIONS AND SUGGESTIONS}

\section{Conclusions}

Based on the results of the analysis of feminism studies in the poem entitled Dongeng Marsinah by Sapardi Djoko Damono, a conclusion can be drawn that the literary works of poetry analyzed to have a close relationship with feminism theory in literary theory. In the poem Dongeng Marsinah, a woman named Marsinah who is considered unimportant until the last moment of her life must accept violence both physically, psychologically, as well as sexual violence. The expression of the meaning or image of women in the poem titled Dongeng Marsinah by Sapardi Djoko Damono describes violence and stereotypes that are accepted by women. As a gift from God, women must be protected and loved without committing inhuman acts in the form of violence. Sapardi's work tells the story of Marsinah as a woman who continues to receive stereotypes and violence by some people who feel aggrieved. As a woman, Marsinah is seen as a weak and helpless figure, because as a woman. The most prominent critique of feminism in the poem is that women are described as gifts from God that must be preserved, without violence and abuse by men.

\section{Suggestions}

The expression of the meaning or image of women in the poem titled Dongeng Marsinah by Sapardi Djoko Damono describes violence and stereotypes that are accepted by women. As a gift from God, women must be protected and loved without committing inhuman acts in the form of violence. Sapardi's work tells the story of Marsinah as a woman who continues to receive stereotypes and violence from some people who feel aggrieved. As a woman, Marsinah is seen as a weak and helpless figure, because as a 
woman. The most prominent criticism of feminism in the poem is that women are depicted as gifts from God that must be preserved, without violence and abuse by men.

With the analysis carried out by the author, it is hoped that the community component can take a lesson from the study of feminism in the poem entitled Dongeng Marsinah by Sapardi Djoko Damono, a feminist critique approach or suggestion that the tragedy of the murder of Marsinah can be a lesson that a woman should not be treated with violence in a general way. physical, mental, or sexual. In addition, the government should be able to investigate Marsinah's problem, which has not met justice.

\section{REFERENCES}

Dipa Nugraha, S. (2021). Kritik dan Penelitian Sastra. Muhammadiyah University Press.

Djajanegara, S. (n.d.). Kritik Sastra Feminis: Sebuah Pengantar. Gramedia Pustaka Utama.

Jenggawah, N., Pada, S., Berpikir, K., Dan, K., \& Belajar, M. (2010). Digital Digital Repository Repository Universitas Universitas Jember Jember Digital Jember Digital Repository Repository Universitas Universitas Jember. 68-74.

Kosasih. (2012). Dasar-dasar keterampilan bersastra. Yrama Widya.

Mustofa, K., Hasyim, W., Feminisme, K., Zuraida, T. R., \& Qomariyah, U. (2013). Pemberontakan Perempuan Dalam Novel Perempuan Badai Karya Mustofa Wahid Hasyim: Kajian Feminisme. Jurnal Sastra Indonesia, 3(1), 1-10.

N. Hamidah, Endang, F. N. (n.d.). Pandangan Dunia Pengarang dalam Novel Putri Karya Putu Wijaya. Journal of Feminism and Gender Studies Universitas Jember, 2(1), 83-110. http://repository.unej.ac.id/handle/123456789/104352

Novel, D., Heights, W., \& Emily, K. (2021). Info Artikel Sejarah Artikel. 5(1), 19-34.

Olifia, S. (2016). Representasi Feminisme Dalam Karya Sastra. S:JK Semiotika: Jurnal Komunikasi, $\quad$ 10(2), https://journal.ubm.ac.id/index.php/semiotika/article/view/951 439-466.

Pradopo. (1995). Beberapa Teori Sastra, Metode Kritik dan Penerapannya. Pustaka Pelajar.

Sapardi Djoko Damono. (2015). Melipat Jarak (pp. 7-12). Gramedia Pustaka Utama.

Sulkifli, \& Marwati. (2016). Kemampuan Menulis Puisi Siswa Kelas Viii Smp Negeri Satu Atap 3 Langgikima Kabupaten Konawe Utara. Jurnal Bastra, 1(1), 1-22. http://ojs.uho.ac.id/index.php/BASTRA/article/view/1058 
Sutopo. (2002). Metodologi Penelitian Kualitatif. Sebelas Maret University Press.

Wijayanti, Y., \& Siroj, M. B. (2020). Analisis Kesalahan Bahasa Tulis Pemelajar Bahasa Indonesia Bagi Penutur Asing (BIPA) Level 2B Wisma Bahasa Yogyakarta. Jurnal Sastra Indonesia, 9(2), 90-96. https://doi.org/10.15294/jsi.v9i2.31568

Zulfadli. (2018). Citra Perempuan dalam Kumpulan Puisi Karya Sapardi Djoko Damono. Jurnal UNTAD, 3(1), 16-28. 